\title{
A LO LARGO DE LA ATALAYA: EL TRAVELLING DESCREÍDO DEL OPENING DE THE YOUNG POPE (PAOLO SORRENTINO, 2016)
}

\section{ALONG THE WATCHTOWER. THE GODLESS TRAVELLING OF THE YOUNG POPE'S OPENING (PAOLO SORRENTINO, 2016)}

\author{
IVÁn Bort GuAL \\ (CESAG-UP Comillas) \\ Teresa SOROLla-Romero \\ (Universitat Jaume I)
}

\section{RESUMEN}

Con paso decidido, las manos a la espalda y sonrisa altiva, un joven vestido con la túnica alba camina por una galería de paredes granates iluminada mediante un suave claroscuro. Un travelling de pulso tan estable como firme es su avance acompaña su paso. La mirada de la cámara va dejando atrás lienzos que el caminante no atiende, mientras bajo ellos, a modo de cartela identificativa pero con parpadeantes luces de neón, van apareciendo los títulos de crédito de la serie The Young Pope (Paolo Sorrentino, 2017). El friso de imágenes cronológicamente desordenadas muestra escenas religiosas de diversas épocas y estilos, hilvanadas por una suerte de estrella de oriente que se vuelve progresivamente destructiva al ritmo del crescendo de la banda sonora e incendia las escenas de los lienzos, cuyo cielo va cruzando. La estrella guía, convertida en meteorito, termina impactando sobre una escultura de Juan Pablo II para conformar La nona hora (Maurizio Cattelan, 1999). El guiño que Lenny, o Pio XIII, dirige al espectador transgrediendo la cuarta pared justo antes del choque avanza rasgos clave del carácter del pontífice protagonista, pues entronca con referentes previos cinematográficos y televisivos. En este texto pretendemos llevar a cabo un análisis del opening de The Young Pope que lea el significado que emerge de la colisión entre las referencias pictóricas que la partícula narrativa aúna mediante el andante travelling, así como situarla como conjunto dentro de la tradición que la televisión contemporánea ha venido forjando durante las últimas décadas.

Palabras clave: The Young Pope, Paolo Sorrentino, series de televisión, ficción televisiva, pintura y cine, $\mathrm{HBO}$.

\section{ABSTRACT}

With firm step, the hands behind his back and haughty smile, a young man dressed in a white tunic walks by a gallery illuminated by a soft chiaroscuro. 
A stable traveling accompanies his firm steps. The camera's gaze leaves behind paintings that remind unattended by the walker. Under them, The Young Pope's credits appear on neon lights, as if they were giving information about the paintings. The frieze of chronologically disordered images from different epochs and styles is stitched by a kind of Star of Bethlehem, which becomes progressively destructive and sets fire to the painted scenes. The guide star, transformed in a meteorite, finally impacts with a sculpture of John Paul II and becomes La nona hora (Maurizio Cattelan, 1999). The wink that Lenny dedicates to the spectator breaking the fourth wall advances some key traits of the young pope's character, by reminding previous examples of this gesture from cinema and television as well. In this article we intend to analyse The Young Pope's opening, attending to the meaning born from the collision between the pictorial references showed along the travelling.

Keywords: The Young Pope, Paolo Sorrentino, Television Series, Television Fiction, Painting and Cinema, $\mathrm{HBO}$.

\section{RESUM}

\section{Al llarg de la talaia: el travelling descregut de l'opening de The Young Pope (Paolo Sorrentino, 2016)}

Amb pas decidit, les mans a l'esquena i somriure altiu, un jove vestit amb la túnica alba camina per una galeria de parets granats il.luminada amb un clarobscur suau. Un travelling de pols tan suau com ferm és el seu avanç li acompanya el pas. La mirada de la càmera va deixant enrere llenços que el caminant no atén, mentre sota ells, van apareixent els títols de crèdit de la sèrie The Young Pope (Paolo Sorrentino, 2017) en forma de llums de neó que pampalluguegen. El fris d'imatges cronològicament desendreçades mostra escenes religioses d'èpoques i estils diferents, enfilades per una mena d'estrela d'Orient que esdevé destructiva al ritme del crescendo de la banda sonora $\mathrm{i}$ incendia les escenes dels llenços, el cel dels quals va creuant. L'estrella guia, convertida en meteorit, impacta finalment sobre una escultura de Joan Pau II per conformar La nona hora (Maurizio Cattelan, 1999). Lenny, o Pius XIII, fa l'ullet a l'espectador tot transgredint la quarta paret precisament abans del xoc- avança trets clau del caràcter del pontífex protagonista, atès que entronca amb referents previs cinematogràfics $i$ televisius. En aquest text pretenem dur a terme un anàlisi de l'opening de The Young Pope que llegeixi el significat que emergeix de la col.lisió entre les referències pictòriques que la partícula narrativa condensa mitjançant el travelling caminant, així com situar-la tot formant part de la tradició que la televisió contemporània ha forjat durant les últimes dècades.

Paraules clau: The Young Pope, Paolo Sorrentino, sèries de televisió, ficció televisiva, pintura i cinema, $\mathrm{HBO}$. 
«There must be some way out of here...» All Along the Watchtower (Bob Dylan, 1967)

En torno a 1301-1303, Giotto pintaba una naturalista imagen de una rocosa bola de fuego surcando el cielo y dejando tras ella una estela cónica, decreciente, para ilustrar de forma insólita hasta el momento la estrella de Belén en la Adoración de los Reyes Magos de la Capilla Scrovegni, en Padua. Contagiando a la imagen religiosa de un naturalismo que reflejaba la deriva hacia el humanismo moderno y se retroalimentaba con los avances matemáticos y astronómicos de su época, ${ }^{1}$ el artista florentino pudo inspirarse para su estrella en la visión del cometa Halley, cuyo arrastre sideral pudo observarse desde la Tierra en 1301.

La conversión de una estrella de ocho puntas definidas en una masa chisporroteante muy similar al cometa Halley de Giotto es seguida en el opening de The Young Pope (Paolo Sorrentino, 2016) por Lenny Belardo, el ficticio papa norteamericano que adopta el nombre de Pío XIII. El cometa atraviesa, como cosiéndolas, nueve imágenes que representan momentos clave de la Historia de la Iglesia Católica, y que marcan una deriva hacia la violencia enfatizada por los desperfectos e incendios que el astro provoca en sus escenarios, que más adelante comentaremos. El seguimiento de la estrella se vuelve, en este caso, destructivo. Si la estrella de Belén llevaba a los Reyes Magos de Oriente hasta el recién nacido niño Jesús, de ese punto de partida -promesa de salvación- arranca el cometa del opening para atravesar diferentes etapas de la Historia de la lglesia desde su fundación y primer papado hasta las guerras de religión de los siglos

1 "Art historians view Giotto as the first painter who made physical truth a central element in his work (Gilbert, 1966). This judgment is based on an analysis of the actual works as well as on early sources, which frequently rely on topoi drawn from literary traditions on ancient art" (Olson y Pasachoff, 2002: 1564). 
XVI-XVII, pasando por concilios ecuménicos, llamadas a las cruzadas, etc. Si diversas de las pinturas representan -aunque desde puntos de vista religiosos determinados-acontecimientos históricos, lo naturalista de la representación que entronca con Giotto cae literalmente, siguiendo las leyes de la física, cuando la estrella convertida en meteorito derriba una escultura de Juan Pablo II con la complicidad del apuesto y joven papa que acaba de guiñar ojo al espectador, saliendo fuera de campo antes de la caída del anciano pontífice.

En las páginas que siguen nos proponemos analizar la secuencia de títulos de crédito inicial de la serie, buscando el sentido tanto a las obras de arte que en ella aparecen como a los gestos estéticos y narrativos sobre los que se configura el opening. Los cimientos epistemológicos sobre los que se sustenta nuestra aproximación al mismo -para cuya aparición debemos esperar hasta el tercer episodio, debido a la mayor duración de los dos primeros-, desde el análisis textual de corte semiótico-estructuralista, descansan sobre dos nociones de base: 1) el opening como pieza autónoma susceptible deconstrucción desde la perspectiva de un cierto microanálisis fílmico; y 2) la convicción de que todo opening debe considerarse una partícula epítome concentradora y condensadora de las características formales y de contenido del texto en el que se integra² (Bort Gual, 2012).

\section{El travelling paseante}

All Along The Watchtower, escrita originalmente por Bob Dylan ${ }^{3}$ en 1967 para su álbum "John Wesley Harding" y versionada y popularizada más tarde por muchos otros artistas - siendo quizá la de Jimi Hendrix la más conocida- es la canción que acompaña al opening de la serie $E l$ joven papa (The Young Pope, Paolo Sorrentino, 2016), en una versión instrumental interpretada por Devlin e integrada en su álbum A Moving Picture, cuyo título resuena mutuamente con el deslizarse de los lienzos del opening que nos ocupa, como veremos más adelante. Gestada en un momento especialmente significativo de su carrera, All Along The Watchtower ha sido frecuentemente analizada por su inusual estructura de composición y

2 Javier Moral (2004) propone una hipótesis similar en relación a los main title shots de biopics de artistas de diversas épocas.

3 No es la primera vez que un tema de Dylan es utilizado para estos menesteres, pues la extraordinaria y reveladora pieza de créditos iniciales del film Watchmen (Zack Snyder, 2009), diseñada por el estudio yU+co, discurría al son de la emblemática The Times They Are A-Changin'. 
por su supuesta inspiración en el Libro de Isaías y la caída de Babilonia, ${ }^{4}$ además de por su controvertido mensaje. Desde el título ya se apunta hacia una aparente incorrección, un bello desliz poético del que partiremos para nuestro análisis: si entendemos por watchtower una torre de vigía - lugar que asociamos fácilmente a esa atalaya de la Basílica de San Pedro del Vaticano desde la que el protagonista divisa el mundo-, resulta bastante evidente que se trata de un espacio fijo donde se está, pero que no se puede recorrer, es decir, donde no ha lugar un all along. No obstante, transcribiendo la letra al lenguaje fílmico, sí es el travelling el movimiento de cámara por excelencia para asociar a un a lo largo de, es decir, el seguimiento de un desplazamiento. Y ese es, quizá por ello, el movimiento de cámara que opera en el opening de The Young Pope: el travelling.

Decía Jean-Luc Godard que el travelling es una cuestión moral: acicate ineludible de sus agitaciones sociopolíticas a través de la forma fílmica. No en vano alguno de los travellings más memorables de la historia del cine pueden rastrearse desde su filmografía, particularmente el que encontramos en Week-end (1967) - año precisamente en el que Dylan compone All Along The Watchtower-, donde un travelling de casi diez minutos de duración recorre un monumental atasco automovilístico en clave de mordaz crítica al atolondramiento burgués. Con mucho menor azote político pero idénticos planteamientos formales, hemos podido ver con posterioridad travellings en clave de filigranescos planos-secuencia automovilísticos en el arranque de los coloristas musicales Las señoritas de Rochefort (Les Demoiselles de Rochefort, Jacques Demy, 1967) - nuevamente 1967- o La ciudad de las estrellas (La La Land, Damien Chazelle, 2016) e incluso en videoclips como el Golden (Sia y Travie McCoy, 2015).

Y es que todo travelling, como operación de titánico dirigismo de la mirada espectatorial, se asocia indefectiblemente con una decisión del ente enunciador. "Es fundamental el uso semántico del travelling frente a la dialéctica clásica de plano-contraplano. Mientras esta funciona suponiendo un fuera de campo estrictamente habitado y en tensión de corresponderse, el travelling tiene la función de reunir, de crear un campo lleno" (Bort Gual, Forner Domingo y García Catalán, 2011 : 21). De todo ello dispone con especial maestría la escritura fílmica del talentoso cineasta napolitano Paolo Sorrentino, artífice absoluto de la creación de The Young Pope y en el escarbo de cuya obra nos detenemos para reconocer la inscripción autoral de la

4 Una referencia que no resulta descabellada, atendiendo a las connotaciones relativas al caos y desentendimiento bíblicamente asociados a Babel y el levantamiento y derrumbe de su torre. 

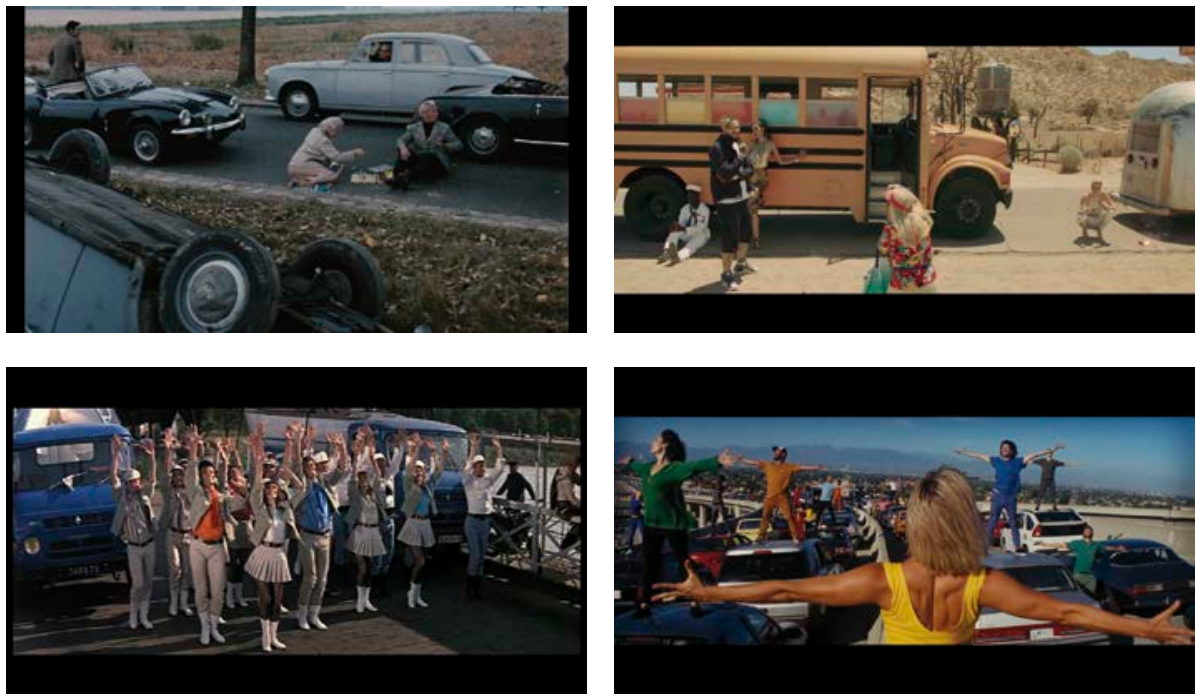

Figs.- 1- 4. Fotogramas de Week-end (arriba a la izquierda), Golden (arriba a la derecha), Las señoritas de Rochefort (abajo a la izquierda) y La ciudad de las estrellas

(abajo a la derecha).

partícula a estudio. Ya en esta misma dirección versaban los títulos de crédito de su hipnótica y desasosegante Las consecuencias del amor (Le conseguenze dell'amore, 2004), donde Sorrentino nos obsequiaba con un plano inicial que amenazaba con hacer estallar la paciencia del espectador. Una composición en llamativa profundidad de campo muestra una cinta de desplazamiento de un aeropuerto, uno de esos enclaves muy dados al travelling - por el movimiento constante y por la noción de viaje (travel) - . Sin embargo, el plano que escoge Sorrentino para desesperar la narración es sostenido, fijo, estático. La música: metálica, distante, maquinal. Al fondo parece vislumbrarse un hombre con una maleta, solitario, único elemento divisable en el plano, pero muy lejano aún. Pronto deducimos, resignados, que la secuencia de títulos de crédito durará, por lógica, todo el tiempo que al plano le cueste que ese hombre con la maleta que se acerca con la parsimonia de una cinta de transporte que se nos antoja infinita llegue a nuestra posición, la de la cámara, que no se ha movido un ápice. No hay aquí, pues, travelling, no hay espacio para el seguimiento. $Y$ es que eso es precisamente el travelling: una cuestión acerca del t(i)empo de la narración en recorrer un espacio con o sin un personaje. Por eso Lenny -o Pío XIIIguía el opening de The Young Pope, porque el travelling es el que le sigue. La decisión formal de Sorrentino para el opening de The Young Pope es 

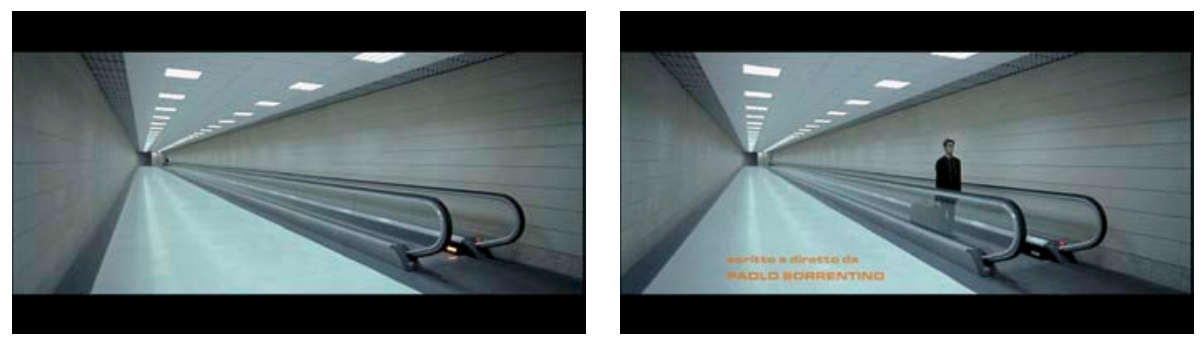

Figs.- 5 y 6. Fotogramas del plano inicial de Las consecuencias del amor.

similar a la que emplea en II Divo (2008) para seguir a otro mandatario, en este caso al primer ministro italiano Giulio Andreotti, caminando no ante pinturas, sino ante pintadas: unos feos grafitis de denuncia en la pared en contra de su política: "Masacres y conspiraciones, el trabajo de Andreotti". Su andar pasmoso, manos en la espalda, y su rostro impertérrito al transitar ante ellas muestra su total indiferencia, algo que encuentra su reflejo en la actitud indolente de Pío XIII al avanzar sobre los cuadros que retratan algunos de los episodios de la historia de la Iglesia Católica -y que más tarde analizaremos-.
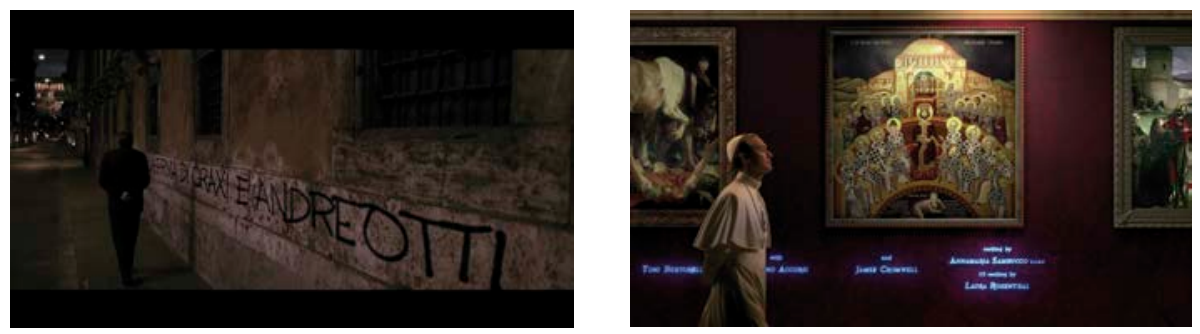

Figs.- 7 y 8 . Fotogramas de II Divo (izquierda) y del opening de The Young Pope (derecha).

En II Divo Sorrentino despliega un opulento aparato formal -tanto como el del propio gobierno representado- donde el travelling de seguimiento sumado a un cierto efecto de ralentización sirve para presentar a la literalmente $-y$ no muy sutilmente rotulada en rojo- denominada corriente andreottiana de la democracia cristiana-. Así, nuevamente, la presentación de este variopinto y patético grupo de personajes - entre los que no falta tampoco un cardenal visiblemente ataviado con sus púrpuras vestimentas 
litúrgicas y birreta - reviste reminiscencias con el palmito de Pío XIII en el opening de The Young Pope. Todo ello, aún más si cabe, se refuerza visualmente con una composición del plano que los bandaliza al mismo tiempo que los patetiza en un claro intertexto a los títulos de apertura de Reservoir Dogs (Quentin Tarantino, 1991).
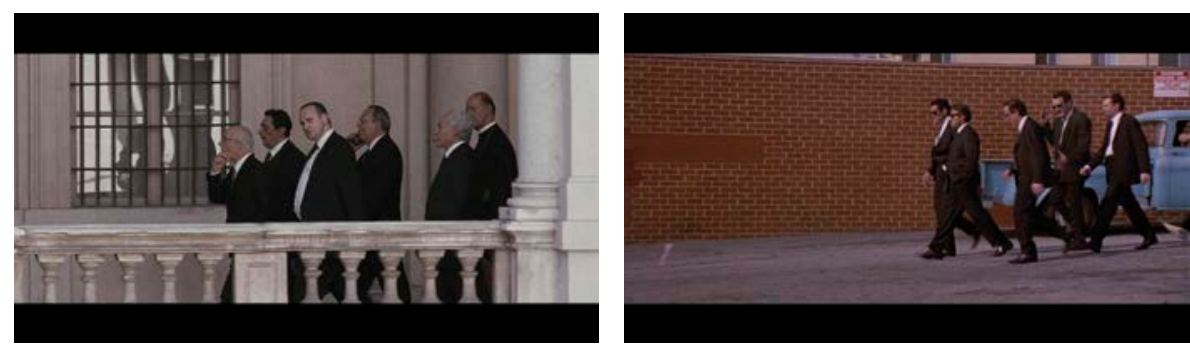

Figs.- 9 y 10. Fotogramas de II Divo (izquierda) y de Reservoir Dogs (derecha).

El modo en el que el personaje interpretado por Jude Law recorre el opening - paso decidido, manos en la espalda, sonrisa altiva e incluso indumentaria blanca - entronca también con el modo en el que Jep Gambardella (Toni Servillo), icónico personaje protagónico de la también sorrentiniana La Gran Belleza (La Grande Bellezza, 2013) se desplaza por la noche taciturna de la Via Veneto romana. Aquí la referencia pertinente es la del flâneur de Charles Baudelaire, ese caballero que pasea por las calles de la ciudad sin un rumbo ni objetivo, artista indolente, literato decadentista del cual el poeta diría que se queda "el último allí donde la luz brille, donde resuene la poesía, hormiguee la vida y vibre la música" (1988: 1381). Eso es Jep Gambardella y eso es también, en cierto modo, el Papa Pío XIII de The Young Pope. En El puente de Europa de Gustave Caillebotte (1876), la figura del observador flâneur asumía una mirada reflexiva sobre los acontecimientos urbanos. Un personaje con sombrero y levita "gira la cabeza para observar a la mujer que acaba de sobrepasar, con lo que se evidencia uno de los mayores atractivos para esta figura masculina, la posibilidad del encuentro erótico con una mujer desconocida" (Cuvardic García, 2012: 17). Lo mismo sucede en La Gran Belleza, cuando en uno de esos paseos nocturnos, el personaje que interpreta Toni Servillo, inequívoco alter ego del propio Paolo Sorrentino, se cruza -en un momento de mágico lirismo 
nostálgico - con Fanny Ardant, viuda y musa última de François Truffaut: en realidad Sorrentino está erotizando un cine que admira y homenajea, pero que es consciente de estar remezclando inevitablemente. "A Sorrentino le interesa la madurez y le atrae cada vez más la decadencia [...] todos son retrasados, están desfasados; retrata criaturas que (mal/sobre)viven apegados al pasado; anacrónicas por rechazo de los valores de la época contemporánea; víctimas y verdugos del autoengaño; aspirantes a héroes en un imposible pretérito mítico; e impotentes. Apenas se rebelan contra el hado tanto más terrible de la intrascendencia y el patetismo irredimible de los especímenes condenados a extinguirse sin transferir su legado a progenie alguna" (Rubio Alcover, 2012: 229). Residuos del tedio decimonónico, de la inacción del dolce far niente, salpicarán también los paseos, descansos y rezos del papa por los jardines vaticanos y los quehaceres blandamente deportivos o domésticos que ocupan a las monjas en los exteriores palaciegos -recoger naranjas, lavar o tender la ropa...-.

Las traslaciones de la poética del flâneur a la ontología del arte cinematográfico han ido más allá de la mera representación del personaje, concibiendo la mirada de la cámara como una flanerie urbana, "sobre todo cuando se toma en cuenta que ambas actividades se caracterizan por la movilidad, es decir, son actividades peripatéticas que desarrollan una visualidad fragmentaria y caleidoscópica, [...] las similitudes entre la mirada del flâneur y el registro visual de la cámara cinematográfica se dan, sobre todo, en el documental, y dentro de este, en el subgénero de la sinfonía urbana, que registra las variaciones en el ritmo de las actividades callejeras" (Cuvardic García, 2012: 20). Por ello no resulta descabellado vincular los mecanismos discursivos de El hombre con la cámara de Dziga Vertov (Chevolek s kinoapparátom, 1929), A propósito de Niza de Jean Vigo (À propos de Nice, 1930), o de Berlín, sinfonía de una ciudad de Walter Ruttmann (Berlin Die Sinfonie Der Grosstadt, 1927) con las operaciones del dandi ocioso - más tarde veremos que la mirada de Pío XIII es clave en The Young Pope-. De hecho, tampoco lo es hacerlo con el amanecer sonoro de las calles de París registradas por Rouben Mamoulian en Ámame esta noche (Love Me Tonight, 1932) o con la inscripción de los personajes femeninos en los espacios urbanos del cine de Michelangelo Antonioni -sobre todo la Monica Vitti de La noche (La Notte, 1961), El eclipse (L'éclisse, 1962) y El desierto rojo (II deserto rosso, 1962)- e incluso la actualización que de todo ello supone Lost in translation (Sofia Coppola, 2003). Sugestivas cuestiones en cuyo detenimiento no podemos sucumbir por desviarnos del análisis al que aquí atendemos. 


\section{LO VIEJO Y LO NUEVO}

En esa poética de lo viejo y lo nuevo puede entenderse gran parte de la propuesta fílmica de Sorrentino. De cómo su cine bebe de la fuente de Federico Fellini, de quien recoge su interés por la representación de la religión y, sobre todo, de la fascinación por la litúrgica religiosa de la que hace gala en The Young Pope. Al mismo tiempo su impronta es la del cine de su tiempo, una cuestión que trasluce de forma brillante en una escena del segundo episodio, en la que el nuevo Papa discute las estrategias de comunicación con su gabinete y en la que parece que es el propio Sorrentino quien traza realmente su mapa de (p)referencias, donde "Pío XIII enfrenta la oscuridad a la visibilidad, favorece el misterio a la transparencia, obliga a reivindicar la etiqueta de lo oculto como el antídoto contra el discurso banal de lo cotidiano, la célebre gerede heideggeriana" (Rodríguez Serrano, 2017: 90). En su ilustrativa conversación con Sofia (Cécile de France), jefa de márquetin del Vaticano, dice:

- Ahora que lo pienso, llevo toda la vida preparándome para ser un papa invisible, y en mi primer discurso, la luz será tan tenue que fotógrafos, cámaras de televisión o fieles, no verán nada de mí, solo una sombra oscura, mi silueta, no me verán porque no existo [...] ¿Suicidio mediático? Sígame, si puede: ¿El autor más importante de los últimos veinte años? Atención, no el mejor, el virtuosismo es de arrogantes, el más importante, ese que ha despertado tal morbo y curiosidad que le han hecho el más importante.

- ¿्Philip Roth?

- ¡No! Salinger. ¿¿irector de cine más importante?

- ¿Spielberg?

- ¡No! Kubrick. ¿Artista contemporáneo?

- ¿̇Jeff Koons, Marina Abramovic?

- ¡No! ¡Banksy! ¿Música electrónica? ¡Daft Punk! [...] en el Vaticano para sobrevivir hay que hacerse tan inaccesible como una estrella de rock. El Vaticano sobrevive gracias a la hipérbole.

No en balde, prontamente el mentor del joven papa, el cardenal Spencer (James Cromwell), profundamente decepcionado por no haber resultado él pontífice advierte al amedrentado Secretario de Estado Voiello (Silvio Orlando) de que la curia, temiendo su conservadurismo y eligiendo a Lenny, ha pasado por alto que los jóvenes siempre son mucho más radicales que los ancianos. Como el Vaticano, como el joven papa cuando se dirige a los 
cardenales por primera vez en la Capilla Sixtina, entrando enjoyado con la tirara papal en andas sobre la silla gestatoria, la cámara de Sorrentino es hiperbólica, su puesta en escena es siempre excesiva y desmesurada. Así sucede durante la serie desde su onírico arranque hasta su estratosférica despedida que traslada el punto de vista al universo. Del mismo modo que la irrupción misma del joven Papa en ese anquilosado Estado rodeado de eclesiásticos moribundos, sus ideas, sus planteamientos, sus comportamientos, sus excentricidades, vehiculan la narración hacia la dicotomía discursiva, nuevamente, de lo viejo y lo nuevo. En su último filme estrenado en salas - decir su última película, dada la extraordinaria producción de The Young Pope, supondría chafar terrenos pantanosos en esa inerte confrontación entre cine y televisión $-{ }^{5}$, titulado precisamente La juventud (Youth, 2016), Sorrentino no esconde esa preocupación esencial en su obra, y de hecho la explicita con un intertexto -visual pero no narrativo- al prolífico tema bíblico de Susana y los viejos.

\section{La GaLería}

Pío XIII no oculta su desagrado por los turistas -a los cuales manda cerrar las puertas del Vaticano para contemplar tranquilamente La piedad de Miguel Ángel (1498-1499)-. Confiesa al cardenal Gutiérrez (Javier Cámara)
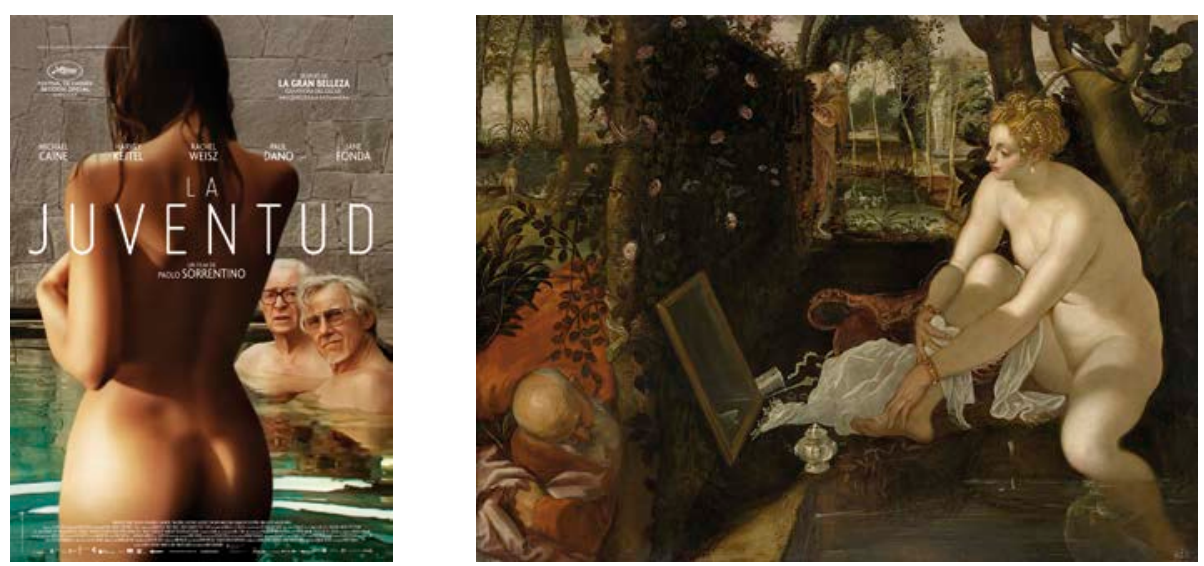

Figs.- 11 y 12. Poster oficial de La juventud y pintura de Susana y los viejos de Tintoretto (1557).

5 Uno de los teóricos que trabajado la complejidad de la serialidad televisiva contemporánea, especialmente norteamericana, es Mittell (2006). 
que le molesta de ellos que "siempre están de paso". Eso es, en esencia, un travelling: un paseo al que la cámara obliga, que va recorriendo y dejando atrás espacio del profílmico. Es delante de la escultura de la Virgen con Cristo muerto sobre los brazos que Lenny -huérfano- reflexiona ante Gutiérrez: "Al final, todo se reduce a la madre". Su trauma vital, el dolor jamás superado por el abandono de sus padres, a los que persigue en sueños por las calles de Venecia y de los cuales no ha vuelto a saber nada, es el eje sobre el que pivota su carácter. Pío no tiene una madre que le sostenga cuando se siente desfallecer -pues lo primero que su figura maternal más próxima, la hermana Mary (Diane Keaton), le dijo al recibirle cariñosamente en el orfanato fue: "No me llames madre. Llámame hermana Mary"-, y el relato insiste en esa falta convocándola desde la imagen como motivo visual recurrente.

Ninguna Piedad forma parte de las obras que aparecen en los títulos de crédito, pues a diferencia de aquélla, éstas tienen un carácter más narrativo que simbólico. ${ }^{6}$ Sin embargo, la única virgen que aparece lo hace en la obra que da inicio a la galería, La adoración de los pastores (1622) del
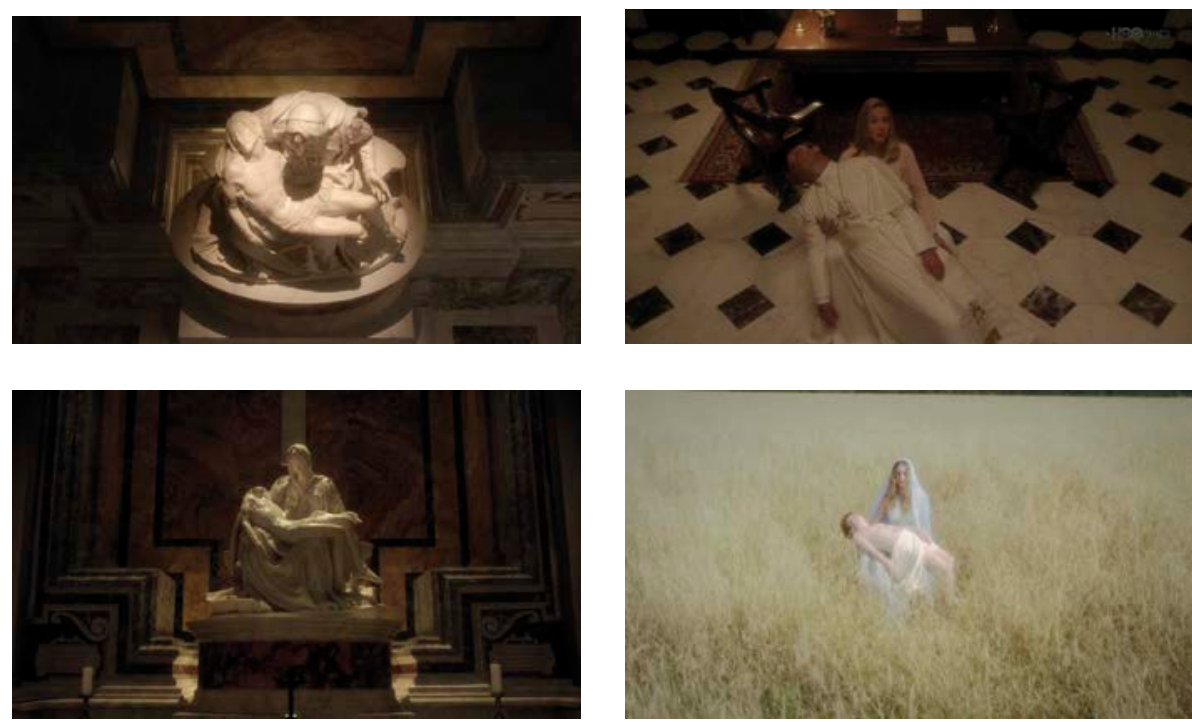

Figs.- 13-16. La piedad recreada literalmente en la serie (izquierda) y a través de composiciones que aluden a ella (derecha). 
caravaggista holandés Gerard van Honthorst, coincidiendo con la acreditación del actor que encarna al papa-Jude Law-. La sagrada familia-de la que Lenny carece- inaugura el paseo, sobrevolada por angelitos y rodeada de pastores que acuden a adorar al niño, expuesto por María que lo descubre sosteniendo delicadamente la tela que le envuelve. El fundacional nacimiento de Cristo -con el cual se compara Lenny constantemente, llegando a declarar que probablemente le supere en atractivo- abre la secuencia. Del niño -la luz del mundo, dirá de sí mismo en el evangelio según san Juan-, y de ninguna otra fuente, emana la luz que baña suavemente al resto de personajes. En contraste con la cándida escena de la adoración, y la bienvenida al mundo que refleja, los bebés que aparecen en la diégesis son portadores de imágenes escalofriantes, apilados como cadáveres holocausticos a las puertas de la Basílica de San Marcos en Venecia, o de súbitos sobresaltos, como el resbalón que provoca la caída de un bebé de los brazos del papa en el hospital. Según Pío XIII se aproxima caminando al lienzo, en su misma dirección y desde dentro del cuadro aparece una estrella dorada, con estela de cometa similar a la Estrella de Oriente que, según la tradición bíblica, guiara a los magos hasta el pesebre. A su paso se aclara la iluminación de los lienzos cuyo cielo surca pero, a medida que avanza, la estrella coge fuerza y muta en una suerte de meteorito incendiario que va causando desperfectos en las escenas que atraviesa hasta derribara al mediático papa Juan Pablo II en La Nona Ora. De este modo, bajo el signo sagrado de buenaventura, bajo el elemento orientador y poéticamente bello, llega -como sucediera en Melancholia (Lars Von Trier, 2011 )- el caos y la destrucción. De hecho, como en Melancholia, también, el filme cierra con un punto de vista inhumano, más que divino, situado en el universo. Sin embargo, donde el filme de Lars von Trier mostraba el asteroide colisionando con la Tierra, The Young Pope inscribe su main title shot sobre un silente planeta Tierra que se va alejando cada vez más, hasta que la tipografía funde con el "The End" definitivo.

Si la primera de las obras se regocija con la llegada del niño al mundo, como con la elección del nuevo papa empieza ilusionándose -fuera de campo- la sociedad católica, la segunda imagen alude ya a la condición de dueño, de soberano de los bienes de la Iglesia que Pío XIII reivindica sin

6 Tal y como han propuesto, respecto a la interrelación entre pintura y cine, diversos autores como -entre otros- Aumont (1997), Bazin (1990), Mitry (1974), Moral (2016), Ortiz y Piqueras (1995) o Sánchez-Biosca (2004) la serie convoca en el opening los lienzos de modo que suponen más que una cita puntual para establecer con el lenguaje cinematográfico una relación más compleja y, en este caso, hablar sobre el relato que los acoge de forma metafórica. 
apuro constantemente. La entrega de las llaves a San Pedro (1482), considerada obra maestra del pintor renacentista Pietro di Cristoforo Vanucci conocido como ll Perugino, es uno de los asombrosos frescos que decoran la Capilla Sixtina y, de hecho, aparece en la serie cuando el papa da allí su primer discurso a los cardenales. La escena queda enmarcada en la matemática perfección de la arquitectura renacentista -y del ventajoso punto de vista desde el que se representa-, inspirada en el arco de Constantino al que aluden los dos arcos triunfales de los lados, y en una idealizada recreación del Templo de Jerusalén representado según los cánones del Renacimiento. La pulcritud de las líneas dirige inequívocamente la mirada hacia un único punto de fuga, y en la parte inferior del mismo queda situado el centro de la acción. De entre un friso de personajes que puebla la parte inferior de la escena -en su mayoría apóstoles, con aureola, y otros ataviados de forma contemporánea entre los que se identifica un posible autorretrato de II Perugino, en el centro destaca Cristo entregando las llaves del Cielo a san Pedro. Las llaves, que cruzadas en forma de aspa forman parte del escudo de armas papal, representan la supremacía de Pedro sobre el resto de discípulos y apóstoles de Jesús y encajan como símbolo de autoridad papal con la reivindicación constante de Pío XIII como cabeza única de la Iglesia Católica. El joven papa reivindica su relación directa con Dios una y otra vez -incluso, desafiante, se equipara al mismo- $y$, en el mencionado discurso a los cardenales que tiene lugar en el quinto episodio, hace referencia a una pequeña puerta dorada ${ }^{7}$ en cuya cerradura resplandece una luz blanca, declarando: "Esa es la puerta. La única entrada. Pequeña y tremendamente incómoda. Todo el que quiera saber quiénes somos tendrá que cruzar esa puerta. Hermanos cardenales, tenemos que volver a ser lo prohibido. Lo inaccesible y misterioso. Esa es la única manera de volver a ser deseables".

Ya la referencia a San Pedro, el primero de los papas, y a su relación personal con Cristo, que le entrega en mano las llaves de los cielos y le encomienda la tarea de dirigir y custodiar la institución eclesiástica, establece un paralelismo con el rol desbordante de poder que se atribuye a sí mismo Lenny como pontífice. Pero además, la materialización de la puerta hace referencia a su potestad para regular la cabida de los fieles en la Iglesia, los márgenes de aceptación de los mismos. No en pocas ocasiones, Pío XIII reclama su soberanía sobre los bienes del Estado Vaticano. En su discurso, alude a la Iglesia como una casa de la que ha decidido expulsar a

7 Metafórica, pero que se materializa en la diégesis a la entrada de la capilla, mágicamente atendida por un suave travelling hacia atrás que deja ver su pequeñez cuando entran en cuadro los cardenales sentados. 

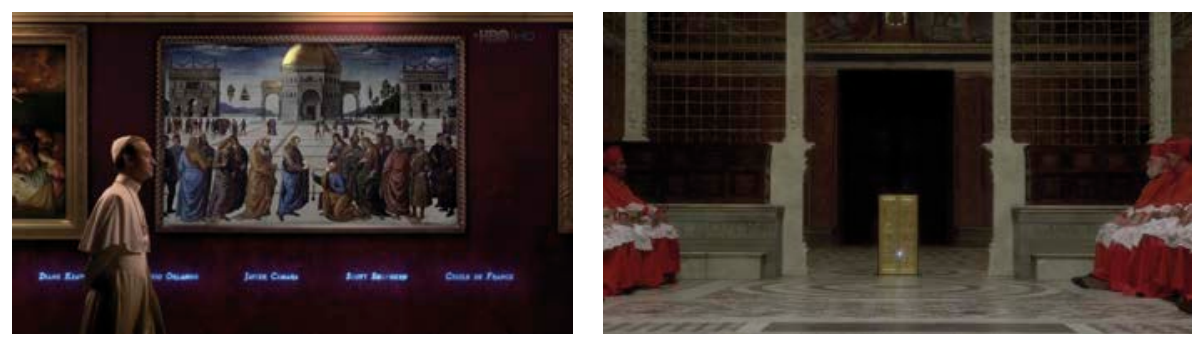

Figs.- 17 y 18. La entrega de las llaves a San Pedro y la pequeña puerta dorada imaginada por Pío XIII.

la tolerancia. Él regula, literalmente, quién entra en ella, y la alusión a lo espacial y lo arquitectónico son centrales en su discurso. ${ }^{8}$ Significativamente, éste se ve reforzado con la terrible enormidad del Juicio Final de Miguel Ángel a sus espaldas, que refuerza la dicotomía entre los que caben, los "fanáticos de Dios" a los que permitirá entrar, y la expulsión de la Iglesia que Lenny tiene en mente, con la que amenaza a la curia, engrandecido en contrapicado y con las miguelangelescas figuras de condenados a sus espaldas: "No hay nada al margen de la obediencia de Pío XIII. Nada salvo infierno [el montaje alterna la pequeña puerta dorada con planos medios del papa]. [...] Un infierno que tal vez no conozcáis, pero yo sí. Porque lo he construido detrás de esa puerta. Infierno. Estos últimos días, lo he construido para vosotros, de ahí la tardanza en hablaros".

La exigencia de absoluta entrega a la fe para los miembros de la lglesia y los fieles presente en los duros discursos del papa no refleja, sin embargo, sus propias creencias, las cuales se revelan en pequeños momentos de

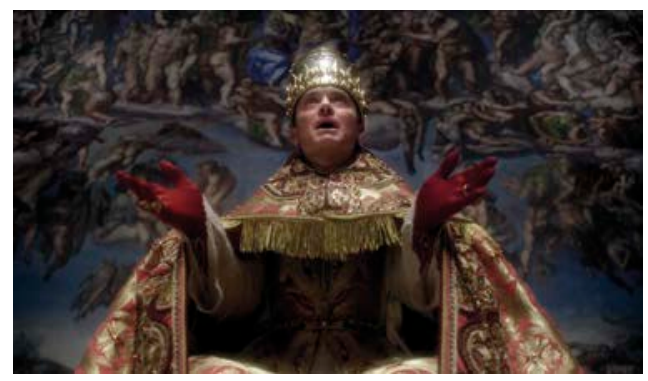

Fig.- 19. Pío XIII engrandecido por la enunciación, con El juicio final a sus espaldas.

8 Dice: "Hermanos cardenales, de hoy en adelante, no estamos, no importa quién llame a nuestra puerta. Estamos, pero sólo para Dios. De hoy en adelante, todo lo que estaba abierto, estará cerrado. [...] ¿ Tolerancia? Ya no vive en esta casa. Ha sido desahuciada. Ha dejado su lugar al nuevo inquilino que tiene gustos diametralmente opuestos en decoración". 
apertura íntima del papa para con personas cercanas a él. Ya al final del primer episodio, tras haber reconocido su afición por confundir a la gente respecto a sus pensamientos e intenciones, Lenny confiesa a don Tomassino (Marcello Romolo) que no cree en Dios para, tras escandalizarle y casi hacerle llorar, decirle que solamente bromeaba. Esa misma confesión que reaparece fragmentada en diversas ocasiones- la retoma seriamente y a corazón abierto en el último episodio ante el cardenal Gutiérrez. Sin embargo, son por lo menos tres las ocasiones en las que Lenny se dirige directamente a Dios para pedirle -exigirle, casi- que ocurran tres improbables sucesos que, efectivamente, se cumplen con la complicidad de una enunciación que en virtud de la iluminación, los encuadres y el punto de vista los dota de un aura especial. Se trata del embarazo de la infértil Esther (Ludivine Sagnier) -en el cual el papa casi parece participar debido al encabalgamiento por montaje de sus oraciones (dice a la Virgen: "debes, debes, debes...") con las embestidas del marido de ella, y su "amén" final con la desconexión de la pareja-, el ataque (y posible fallecimiento) de la corrupta hermana Antonia (Milvia Marigliano) y la curación de la madre de Billy (Andrew Plinio), amigo de la infancia de Lenny. De algún modo, determinados requerimientos del papa parecen ser cumplidos independientemente de sus convicciones religiosas más íntimas y, finalmente, tiene lugar el ansiado discurso masivo, optimista y benevolente que ha estado negando durante toda la serie. Tras el mismo, y habiendo visto con un catalejo a una anciana pareja hippie que Lenny interpreta como sus padres darse la vuelta y alejarse de la plaza veneciana de San Marcos, sufre un dolor en el pecho que le hace caer en brazos de Gutiérrez y el resto de cardenales. Tumbado bocarriba en el balcón de la basílica bizantina, y medio inconsciente, su punto de vista nos muestra una nube en forma de virgen María con los brazos abiertos. Ya sea una alucinación o una visión de tintes milagrosos, en esta escena final opera algún tipo de encuentro que puede rimar con la tercera de las obras del opening: La conversión de San Pablo en el camino a Damasco de Caravaggio (1601). El resplandor de la estrella que Lenny va siguiendo baña el lienzo del maestro del tenebrismo, en el que el todavía soldado romano Saulo cae de su caballo perdiendo la vista, derribado por una poderosa luz. Dice el episodio neotestamentario que, al recuperarse de la ceguera, el soldado que terminaría siendo apóstol, adoptó el nombre de Pablo y se convirtió. No en balde, el personaje escogido es el principal ideólogo teórico del cristianismo sobre cuyas bases crece el catolicismo. Visualmente, además de la caída del protagonista de la escena, la serie sitúa al papa entre los grandes caballos que presiden el balcón de la basílica veneciana desde que fueran expoliados de Constantinopla durante la cuarta cruzada en 1204. 
Si hacia Damasco se dirigía Saulo antes de convertirse en Pablo, y de Constantinopla proceden los caballos de San Marcos, también lo oriental bizantino- organiza y es el eje de El concilio de Nicea (fresco del Gran Monasterio de Meteora, Grecia), la cuarta de las obras del opening. Convocado por el emperador Constantino I en el 325, el primer concilio ecuménico debía reunir representantes de cada diócesis del Imperio para resolver cómo combatir el arrianismo, doctrina que cuestionaba la divinidad de Cristo, proponiéndole como hijo de Dios padre con atributos divinos, pero no como Dios en sí mismo. Sin embargo, a Pío XIII no solamente no le preocupan las contradicciones sino que las reivindica como marca propia, pues ya la mañana en que empieza su papado, en respuesta a la pregunta de "¿Quién eres, Lenny?", responde: "Soy una contradicción. Como Dios. Uno y trino, trino y uno. Como María, virgen y madre. Como el hombre, bueno y malo". La fe ciega, más que en los dogmas, en las reglas de la Iglesia Católica en su más estricta radicalidad -qué es pecado, qué es herejía- es predicada constantemente por el papa, que se reserva el derecho de expulsar de su institución a todo aquél que no cumpla con sus postulados. Incluso cierta discusión teológica entre Lenny y Spencer sobre el aborto es atendida en un plano secuencia en que la cámara serpentea en torno a sus palabras en la Capilla Sixtina. Pero Pío XIII es refractario a la voluntad unificadora del ecumenismo, al debate, a cualquier tipo de concilio -de hecho, termina su discurso a los cardenales diciendo: "De hoy en adelante, eso es lo que el papa quiere. Es lo que la Iglesia quiere. Es lo que Dios quiere"-. En un orden cercano a la simbólica jerarquización espacial de carácter románico, el fresco sitúa a Arrio abajo, aislado bajo los pies del emperador Constantino I, lugar por el que Pío XIII obliga a desfilar a los cardenales, asomando su zapato carmesí para que lo besen. La genuflexión más llamativa en este sentido es la de Voiello, en la cual el papa se regodea particularmente agachando al cardenal con el otro pie, como si tras el discurso materializara en su humillación lo que ya le avisó en el capítulo tercero: "Un papa no es un cardenal. Un cardenal trabaja de forma colegiada. Un papa es absoluto soberano".

Una disposición formal similar, simétrica, en la que el papa queda en el centro organiza al papa y sus cuatro cardenales más importantes tras él, a ambos lados, en su visita nocturna a Tonino Pettola -del que hablaremos a propósito de la siguiente obra-, todos ellos ataviados con la indumentaria que les identifica como la élite del poder vaticano.

Es a partir del siguiente lienzo que la estrella empieza a agarrar fuerza, pierde la pureza de sus puntas y va enturbiándose hasta convertirse en una bola de fuego. Significativamente el lienzo, del pintor romántico Francesco Hayez y titulado Pedro el Ermitaño predica la cruzada (1827-1829), 

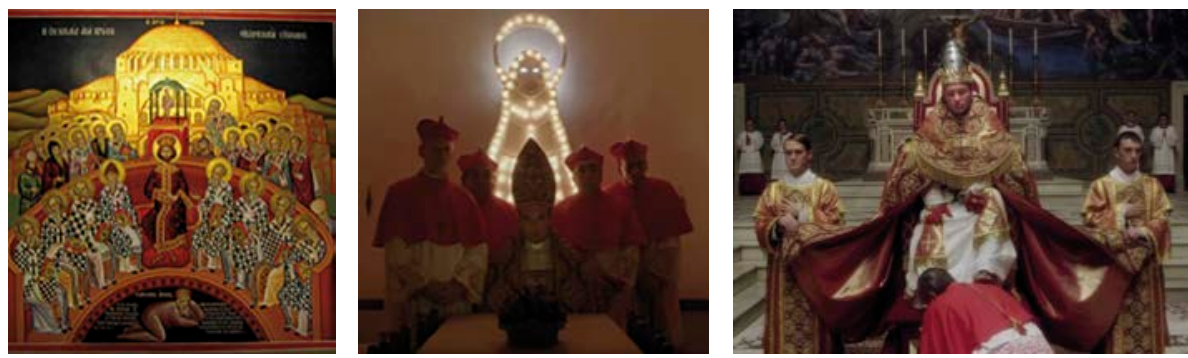

Figs.- 20-22. El concilio de Nicea, la visita nocturna a Pettola y Voiello besando el pie al papa (detalles).

representa una arenga del clérigo francés Pedro de Amiens a la conocida como Cruzada de los pobres, en respuesta a la llamada a la recuperación de Tierra Santa del papa Urbano II -tras el concilio de Clermont, en 1095-. La peregrinación a Jerusalén, encabezada por miembros del bajo clero, terminó con la muerte de buena parte de los cruzados (pueblo llano, en su mayoría) a manos de los turcos selyúcidas en Nicea. La expedición precedió por poco a la que la historia bautizaría como Primera Cruzada -o Cruzada de los príncipes-, ya dirigida militar y estratégicamente por nobles europeos. Pío XIII carece de espíritu cruzado, pues su belicosidad parece dirigirse más hacia los propios miembros de la fe católica que a los de otras confesiones. De hecho, en el episodio sexto, diversos miembros de una orden de apariencia mendicante vestidos con hábitos toscos, descalzos y barbudos se presentan ante él para exigir su renuncia (bajo la amenaza de cisma por parte de su orden). El papa responde, desafiante: "¿ Un cisma? Intentadlo. Os despojaré de todo lo que tenéis. Todo. Vuestras camas, túnicas, calzoncillos, y esos maravillosos monasterios que poseéis en los lugares más encantadores de la Tierra, porque todo eso me pertenece a mí. ¿Estáis dispuestos a vivir en la calle, como San Francisco de Asís? ¿Estáis dispuestos a dormir por el suelo, pisoteados y escupidos por yonquis, vagabundos y borrachos? Yo estoy dispuesto a haceros una guerra sin cuartel. ¿̇Estáis dispuestos a luchar con la única arma de vuestra absoluta pobreza? Me da que no. Y en ese caso, dejad de decir tonterías y compraos unos zapatos porque aquí el aire es irrespirable". Más allá de la falta de empatía con el predicamento de la lglesia para con los eufemísticamente denominados "desfavorecidos", Pío XIII tergiversa la razón de ser del voto de pobreza de los monjes, amenazándoles con hacérselo cumplir a rajatabla, y aludiendo a su condición de amo de los bienes materiales de la cristiandad católica. Mientras, el montaje interno de los planos sitúa en primer término la mano enjoyada del papa sobre el reposabrazos de 
su trono, rematado por cabezas de angelito, y en segundo término los monjes sentados por debajo de él. Con ello, la planificación contrasta la superioridad del papa con su exquisito atuendo y lo desarrapado del resto de religiosos.

Si hay alguien que predica, como Pedro el Ermitaño, con los brazos abiertos en medio del campo conmoviendo a la multitud y obrando mediáticos milagros, no es ningún habitante del Vaticano sino Tonino Pettola (Franco Pinelli). Vestido de forma humilde, como el predicador, Tonino amenaza con fundar su propia iglesia si el papa no reconoce sus poderes curativos, arrastrando consigo -también como el predicador- a un considerable número de sus seguidores.

Como San Francisco, personaje central en la siguiente obra de la galería del opening, Tonino tiene llagas en las manos, supuesta marca sagrada que le emparenta con la imagen Estigmas de San Francisco, del artista
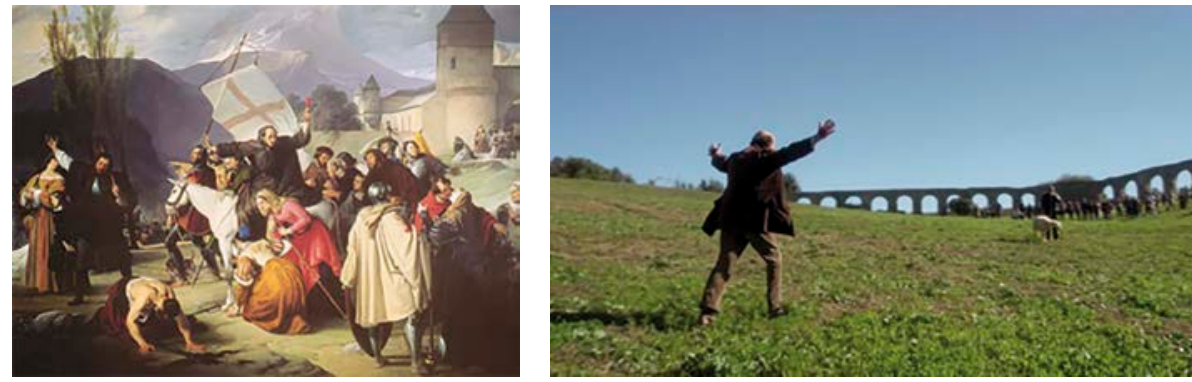

Figs.- 23 y 24. Pedro el Ermitaño predica la cruzada y Tonino Pettola alabando a una cabra en la que ve a la Virgen.

gótico italiano Gentile da Fabriano (1415). En la imagen, el santo recibe los estigmas como rayos dirigidos desde el cielo directamente por un Cristo de apariencia incandescente. De las heridas de Cristo -en las manos, el costado y los pies- varios rayos caen directos sobre los mismos lugares del cuerpo del santo. Sin embargo, los seguidores de Tonino no van a luchar a ninguna parte sino que esperan ser curados por su don -especialmente ducho, explica su ayudante a una afectada presentadora televisiva, en problemas cardiovasculares y de menisco-, y su única petición es para con el pontífice, al cual le pide -mirando a cámara- que reconozca oficialmente su capacidad milagrosa. La reacción de la curia vaticana, y la desconocida -pero "escabrosa", en palabras de Voiello- resolución de la situación, sin embargo, se asemeja más a la de un relato protagonizado por la mafia: 
Tonino se encuentra, al regresar a casa, al papa sentado en su cocina con cuatro cardenales, en la escena mencionada más arriba, sin que se revele nunca por qué el hombre desaparece.

La resolución del conflicto de la corrupción de la hermana Antonia en África y el chantaje respecto al agua al que somete a la población que habita en sus colonias demuestra que para Pío XIII dar limosna no es una solución satisfactoria para la erradicación de la pobreza -conflicto que, no obstante, tampoco demuestra que le importe en demasía si atendemos a sus preocupaciones verbalizadas en conversaciones y discursos. Santo Tomás de Villanueva repartiendo limosna (Mateo Cerezo, 1645), representa al fraile agustino que llegaría a ser arzobispo de Valencia, conocido popularmente por su austeridad y ejercicio de la caridad. En este sentido, en el Libro de la vida y milagros de santo Tomás de Villanueva, se le atribuye la convicción de que el ejercicio de la limosna no termina con dar puntualmente sino que requiere una liberación de la necesidad. En la imagen del prematuramente fallecido pintor barroco Mateo Cerezo, aprendiz en el taller de Carreño de Miranda -el cual llegaría a ser pintor de cámara de Carlos II-, el santo aparece coronado por un angelito y ricamente vestido y, tras él, un sólido fondo arquitectónico clásico y san Agustín portando una cruz -legitimándole-. Con gesto indolente, el santo suelta algunas monedas en un cuenco que sostiene un anciano cojo. La corona de flores que el ángel sostiene sobre Tomás de Villanueva es el primer objeto que arde en el opening cuando la estrella de fuego lo atraviesa. De alguna forma, el particular entendimiento del joven papa sobre la doctrina católica comienza a hacer estragos sobre la tradición que representan las obras de arte escogidas.

Los dos siguientes -y últimos- lienzos del opening acusan también el paso del meteorito por los mismos. Éste atraviesa, al principio, y termina derribando, posteriormente, el parasol rojo que resguarda al papa en Miguel Ángel presentando el modelo de la basílica de San Pedro al papa Pío IV (1619) de Domenico Cresti, conocido como Domenico Passignano. Encargado para la decorar casa Buonarroti en Florencia, el lienzo le muestra vestido sobriamente de negro, señalando con una mano -que tal vez homenajea a la de dios padre en la celebérrima Creación de Adán de la Capilla Sixtina- una maqueta de su proyecto de la basílica de San Pedro, la cual prácticamente tiene entidad de personaje. Rodeado de cardenales y otras figuras masculinas a modo de séquito, el papa también la señala abriendo la mano en un gesto de carácter más interrogante. El caballero situado tras Miguel Ángel interpela al espectador con su mirada, como hará Pío XIII al final el opening, antes de salirse fuera de campo. En la serie, la basílica y el Palacio Apostólico -en contrapunto con los jardines- quedan reforzados por le enunciación como símbolos de poder, más allá de por su intrínseca 
grandeza arquitectónica y exquisitez artística, por la forma de habitarlos de Pío XIII y su utilización como espacio intimidatorio respecto al resto del mundo. Bajo el papado del obispo representado -Pío, como Lenny- culminó el Concilio de Trento, desarrollado intermitentemente desde 1545 hasta 1563. Cuestiones relativas al mismo como el énfasis contrarreformista en la mediación de la Iglesia para la salvación, la jerarquía eclesiástica encabezada por el papa, la defensa teológica de los dogmas rechazados por el protestantismo o la reinstauración de la Inquisición -para combatir, precisamente, a éste-, la unificación litúrgica o la querencia por el despliegue estético de la espectacularidad barroca salpican, aquí y allá, el comportamiento y la opinión -más política que teológica- de Pío XIII. Volviendo al lienzo, en su último plano se recorta un espacio exterior entre las columnas y arcos que merece la pena advertir, pues al fondo aparece parte de la antigua muralla Leonina, que Pío IV mandó reforzar. Como retomando metafóricamente la idea del blindaje, de la defensa hermética, Pío XIII declara en el discurso a los cardenales que venimos mencionando: "Somos cimiento. $Y$ un cimiento no se mueve. Somos cimiento sin ventanas. No miramos al mundo exterior". Casi de forma literal, la fórmula se opone a la voluntad de Juan XXIII de "abrir las ventanas" de la Iglesia para que los clérigos pudieran mirar hacia fuera y los fieles ver su interior con la convocatoria del Concilio Vaticano II.

Tras el lienzo de Passignano, el meteorito contribuye al sanguinario caos de La matanza del día de San Bartolomé, del pintor hugonote François Dubois (h. 1572-84). La última de las imágenes, que representa la masacre de hugonotes que tuvo lugar en París durante las guerras de religión francesas del siglo XVI, es la más violenta de toda la galería que recorre Lenny. La culminación pictórica del opening termina, así, con una matanza de ciudadanos franceses llevada a cabo por los católicos principalmente parisinos con el beneplácito del papa y la monarquía francesa, que en adelante se alineará con las fuerzas católicas abandonando la tolerancia para con las corrientes protestantes que habían penetrado en Francia por influencia calvinista. Del mismo modo que, según avanza la serie, determinados conflictos mundanos, y no espirituales, van emergiendo en diversas tramas, como el alcoholismo, el abuso de menores por parte de sacerdotes, la intolerancia con la homosexualidad que lleva a un muchacho a suicidarse -irónicamente, desde la misma terraza de San Pedro- o el aprovechamiento de una situación relativamente privilegiada ante la falta de recursos en el Tercer Mundo, las pinturas se dirigen desde temas más puramente religiosos -el nacimiento de Cristo, la entrega de las llaves del cielo a San Pedro...- a episodios de la política europea cuyas consecuencias inmediatas rebasan con mucho lo espiritual. 
Mirada con detenimiento, la imagen de Dubois resulta verdaderamente escalofriante: el hugonote denuncia mediante el lienzo decapitaciones, pillaje, asesinatos de niños y de mujeres embarazadas con las entrañas fuera,
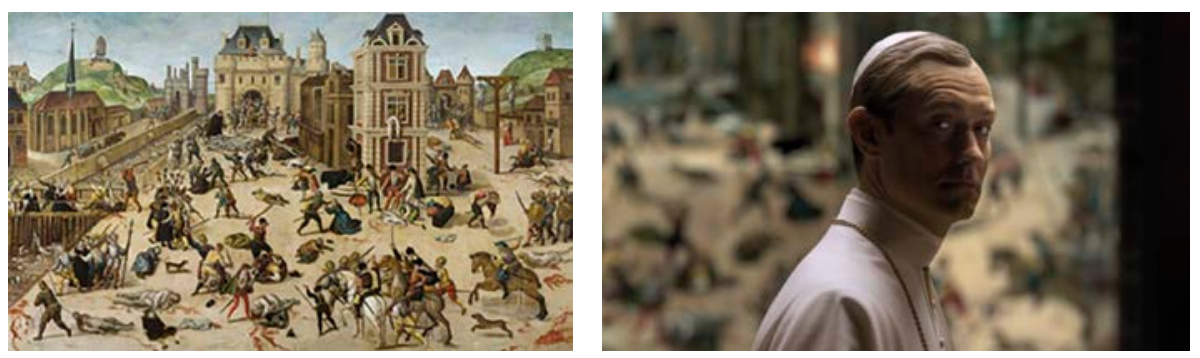

Figs.- 25 y 26. La matanza del día de San Bartolomé y Lenny mirando a cámara ante ella.

cadáveres amontonados y flotando en el Sena. A un lado la reina madre, Catalina de Médici, observa muertos amontonados a la salida del Louvre, mientras por la ventana del edificio que destaca ligeramente a la derecha de la composición, quien pudiera ser el almirante Coligny lya gravemente herido en el atentado que desencadena todo el episodio) es arrojado por la ventana. El único cambio de plano tiene lugar por corte directo desde el plano americano largo que encuadra al papa caminando por la galería a un primer plano cuando éste, precisamente, se encuentra delante de La matanza del día de San Bartolomé, desenfocada a sus espaldas mientras él, sin dejar de andar, se gira para mirar a cámara y guiñar un ojo al espectador. ${ }^{9}$ De este modo, el montaje interno superpone su cómplice media sonrisa al desaguisado desenfocado que queda a sus espaldas, como si disfrutara socarronamente del mismo.

Lenny, satisfecho, continúa caminando y sale de plano mientras el travelling se detiene en una realista, pero agrandada, estatua de Juan Pablo II, que sostiene la férula papal con los ojos cerrados. Un segundo más tarde, un meteorito la derriba y sobre el fondo negro aparece el main title shot en neón azul. El plano se abre para mostrar La Nona Ora (Maurizio Cattelan, 1999): la estatua del pontífice en el suelo, de una pieza, con la oscura y humeante roca aplastándole los pies. Sobre ella, aparece en

9 Gesto en que nos detendremos más adelante. 
la misma tipografía de neón la acreditación de Paolo Sorrentino. Con la alusión a la instalación de Cattelan, el opening tira abajo (por lo menos en su planteamiento inicial) lo que de mediático y popular tuviera Juan Pablo II -también recordado, no obstante, como anticomunista y profundamente conservador, entre otros aspectos, en términos de moral sexual-. Lenny rehúsa convertirse en una figura pública amigable con las cámaras que pasea en papamóvil, del mismo modo que, en principio, rechaza el aperturismo y las facilidades de culto del Concilio Vaticano II escogiendo un nombre previo al mismo y que remite directamente a Pío XII y su firma del Reichskonkordat en 1933 (todavía como cardenal y siendo Hitler canciller), concordato entre la Santa Sede y el Tercer Reich Alemán que establecía las condiciones de libertad religiosa para la Iglesia Católica.

\title{
LA ROTURA de LA CUARTA PARED Y EL PARPADEO dE LAS LUCES DE NEÓN
}

El colofón del opening lo constituye el main title shot de la serie, así como del guiño que el papa lleva a cabo pocos segundos antes de que éste aparezca, el cual transgrede la cuarta pared cuando Lenny apela al espectador con la mirada:

\begin{abstract}
Resulta necesario comenzar pensando cómo funciona la mirada del propio Pío XIII en el interior de la serie. Mirada hacia el mundo, pero también hacia sí mismo. En el primer capítulo por ejemplo, la secuencia de títulos de crédito [...] está construida sobre planos subjetivos del propio Lenny acercándose al balcón papal. [...] El resto de cuerpos que se arremolinan a su alrededor le evitan la mirada. En un momento dado, es el propio crédito el que secciona el rostro del actor y deja reencuadrada, de manera explicita, su mirada y su fingida sonrisa (Rodríguez Serrano, 2017: 89).
\end{abstract}

La autorreferencialidad de la obra de Sorrentino se urde aquí desde el desvelamiento del dispositivo, la consciencia de saberse un constructo ficcional, algo que evidencia especialmente el guiño al espectador que analizaremos. Una buena muestra de ello llega entrado unos minutos ese primer episodio. En una de esas escenas-tipo o secuencias-paradigma aglutinadoras de buena parte del sustrato discursivo de la obra en cuestión, Pío XIII se enciende un cigarrillo. " iSanto Padre! jSanto Padre!..." le espeta el cardenal Voiello: "fumar no está permitido en la residencia papal". Con una suficiencia pantagruélica, dando una gustosa y despreocupada calada al pitillo, Pío XIII le desafía: " ¿̇ eso? ¿̇Quién lo ha dicho?". "Juan Pablo II", le contesta Voiello. " ¿El Papa?" le pregunta de nuevo. "Sí, el 
Papa" confirma el cardenal. Mirándole fijamente, y continuando con ese aire chulesco, Pío XIII concluye: "Ahora hay otro papa". "Cierto", asume con resignación Voiello. Tras unos segundos de silencio para dar una nueva calada, asistimos al siguiente alegato por parte del Papa, que dará sentido a donde queremos llegar: "Eminencia, está usted demasiado atado al pasado. El pasado es un vasto lugar repleto de cosas en su interior. No así el presente. El presente es una estrecha rendija con espacio solo para dos ojos: los míos". Como si el propio Papa hubiese audiocomentado el plano, las palabras de Pío XIII se encarnan en el main title shot que previamente había presentado a la serie, y como tal, El joven papa, a él mismo. Y una vez más, en ese "ahora hay otro papa" y en esa definición gráfica del presente como juventud, retornamos a la idea central sorrentiniana de lo viejo y lo nuevo.

Si bien toda secuencia de títulos de crédito, en tanto rotulación extradiegética, debe ser entendida como una marca enunciativa, que un personaje se dirija explícitamente al espectador y le guiñe el ojo es una ruptura todavía
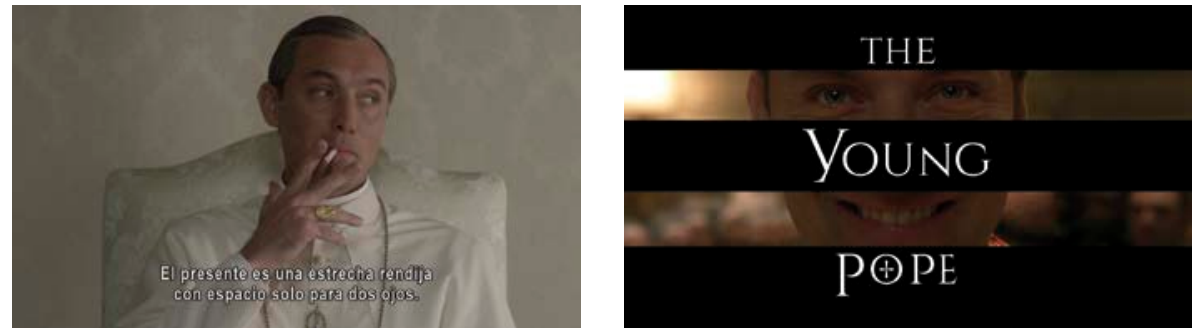

Figs.- 27 y 28. Fotogramas del primer episodio de The Young Pope.

mayor. Lo decimos en esta ocasión en referencia a la denominada ruptura de la cuarta pared o metalepsis narrativa que ha lugar en la parte final del opening de The Young Pope. A aquellos cuyo visionado de su primera temporada e inefable carisma e intratable carácter del susodicho resonó a un trasunto de Frank Underwood de House of Cards (Beau Willimon, 2013-2018) en el Vaticano, esta llamativa decisión del opening vino a confirmar el paralelismo. En la serie norteamericana producida por David Fincher, Frank Underwood, un muy poderoso personaje protagonista, a quien da vida e impagable rostro Kevin Spacey, está constantemente implicándonos en sus fechorías y tejemanejes en la carrera presidencial. Lo hace dirigiéndose a nosotros, espectadores, desde prácticamente el primer plano de la serie, repitiéndolo constantemente en subsiguientes escenas de los episodios posteriores. Esa complicidad, siempre maquiavélica y en 
ocasiones hasta incómoda, se reserva en The Young Pope exclusivamente para el opening. Curiosamente, el de House of Cards, que compartiría con la anterior la monumentalidad de los escenarios, lo arquitectónico de los espacios y la pervivencia de la piedra -el recurso del time-lapse parece pretender poner de manifiesto lo efímero del hombre: los políticos pasan, las instituciones permanecen - no incluye a ningún personaje en la secuencia y explora estrategias discursivas bien distintas. No conviene olvidar que la interpelación al espectador que hace Pío XIII no es solamente una mirada a cámara - como aquella maravillosa de Un verano con Mónica (Sommaren Med Monika, Ingmar Bergman, 1953) - , sino que se trata de un guiño, inequívoco signo de complicidad. En este sentido no podemos dejar de relacionar a este papa -y a ese blanco impoluto de sus vestimentas - con el asaltante de Funny Games (Michael Haneke, 1997), cuyo inolvidable guiño quebraba el vano deseo del espectador de permanecer al margen de tal atroces circunstancias. Relacionado con el emblemático home invasion de Haneke, el guiño final de Jude Law recuerda también al proceder de Dexter Morgan, protagonista de la serie Dexter (James Manos Jr., 2006-2013), cuyo enganche con el espectador se evidenciaba en su excelente opening cuando salía de su casa tras su rutina matutina. Radicalmente distinta, aunque con plano final similar, era la serie de comedia y acción ochentera Magnum (Magnum P.I., Glen A. Larson, 1980-1988), cuyo plano final del opening era, una vez más, una mirada hacia el espectador que se disponía a disfrutar de sus peripecias.

En todo este pastiche de remezclar lo viejo y lo nuevo resulta particularmente llamativa, por escandalosamente formal, la fascinante escena del episodio cinco en el que el Papa se acicala y atavía con su flamante y recién llegada tiara papal al ritmo del tema rompepistas "Sexy And I Know It" (LMFAO, 2011 1). Tampoco hay escrúpulos estilísticos ni remordimientos de intrascendencia cuando en el episodio octavo, en una de las escenas clave de la "transformación" de Pío XIII, la banda sonora escogida es una versión acústica del "Halo" de Beyoncé. Por ello, una vez más, no debería extrañarnos que esa galería de aterciopeladas paredes granates por las que pasea el papa en el opening, hilera de representaciones de valor incontestable de la Historia del Arte, pero sobre las que se iluminan parpadeantes rótulos en chillonas luces de neón; pueda llegarse a interpretar como una suerte de museo kitsch "a lo Hard Rock Café" pictórico en el que el aura de los artistas está convenientemente presa, acristalada y enmarcada. La estética tipográfica es además heredera de la influencia del neon-noir nocturno a golpe de sintetizador ochentero de la secuencia de títulos de crédito de Drive (Nicolas Winding Refn, 2011) (Bort Gual, 2014), de la que también podemos rastrear sus huellas en otros openings de series norteamericanas 

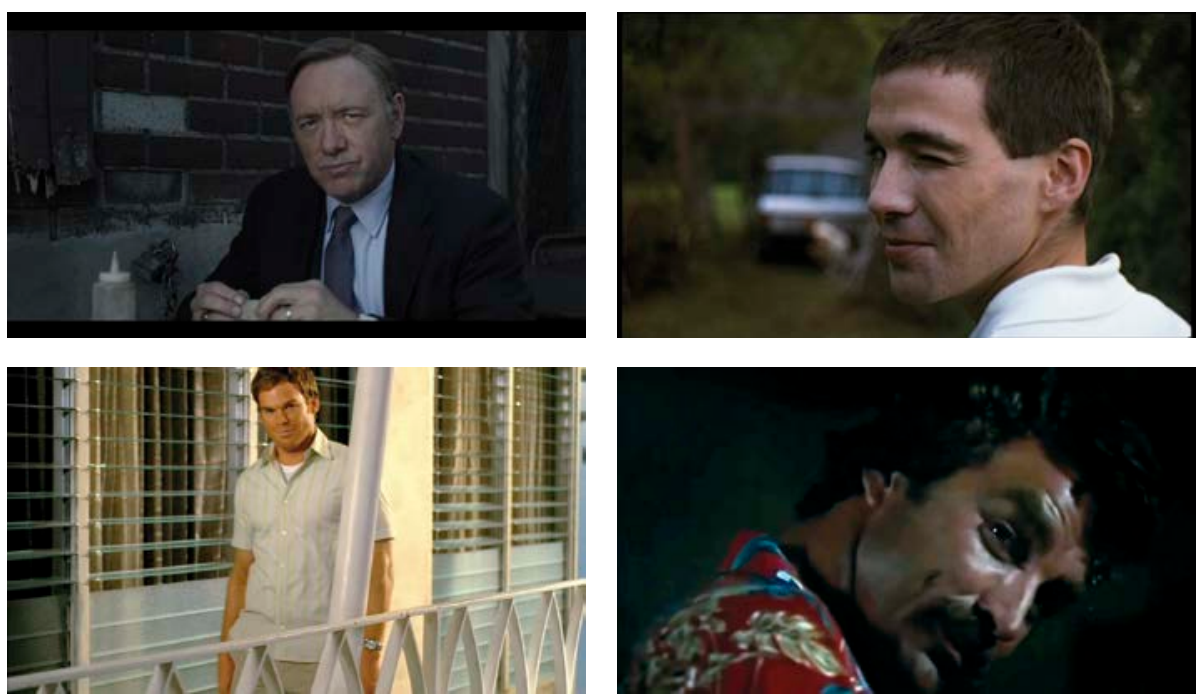

Figs.- 29-32. . Fotogramas de guiños al espectador en el opening de The Young Pope (arriba), House of Cards y Funny Games (centro) y al final de los openings de Dexter y Magnum (abajo).

coetáneas Bates Motel (Anthony Cipriano, 2013-2017) o American Gods (Bryan Fuller, 2017-).

El camino que lleva a Lenny a convertirse en Pío XIII, más allá de ese provocador arranque de la serie en el que el discurso ya se revela producto de la ensoñación maliciosa de un enunciador no fiable, es un trayecto solamente de ida: como el travelling de izquierda a derecha de toda lectura occidental - nada construido más desde la occidentalidad que la Iglesia Católica-. No ha lugar un travelling de vuelta, es decir, de derecha a izquierda, como por ejemplo con el que muy ocurrentemente arranca el film de Pedro Almodóvar titulado, no por casualidad, Volver (2006). Según el propio Paolo Sorrentino: "The paintings of the opening scene are a quick chronological overview, with obvious shortcomings, of the most significant moments in the history and art of the entire arch of Christianity and the church". ${ }^{10}$ "Debe de haber alguna manera de salir de aquí», reza el primer verso del tema de Dylan, quizá velado vaticinio del angustioso sino de Lenny, o de la voluntad divina del ente enunciador del opening. 

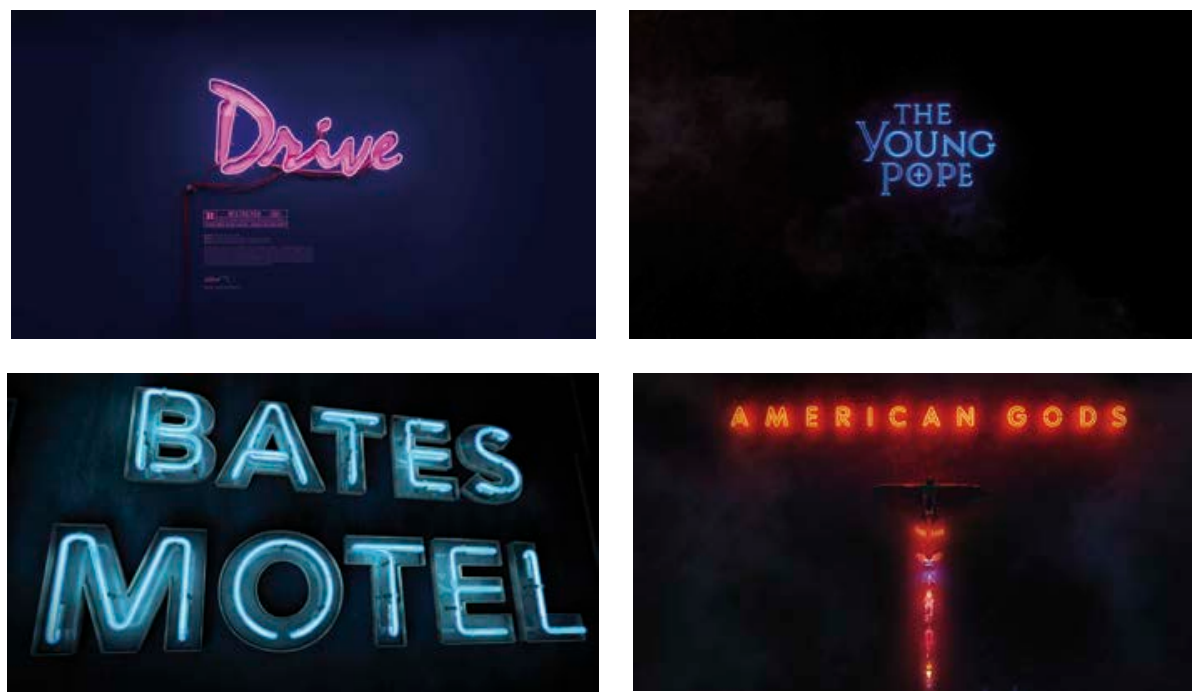

Figs.- 33-36. Main title shots de Drive, The Young Pope, Bates Motel y American Gods.

\section{Biblografía}

AUMONT, Jacques (1997), El Ojo interminable: cine y pintura, Paidós, Barcelona.

BAUDELAIRE, Charles (1988), Curiosidades estéticas, Júcar, Madrid.

BAZIN, André. (1990), ¿¿Qué es el cine?, Rialp, Madrid.

BORT GUAL, Iván, FORNER DOMINGO, Almudena y GARCÍA CATALÁN, Shaila (2011), "Big Love: el travelling lícito", L'Atalante: revista de estudios cinematográficos, $\mathrm{n}^{\circ} 11$, Associació Cinefòrum L'Atalante, Valencia.

BORT GUAL, Iván (2012), Nuevos paradigmas en los telones del relato audiovisual contemporáneo, partículas narrativas de apertura y cierre de las series de televisión norteamericanas, Tesis Doctoral, Universitat Jaume I, Castellón de la Plana.

BORT GUAL, Iván (2014), "La noche de la mistral fucsia", en VV.AA, Análisis de secuencias 2: técnicas de realización, Iconol4, Madrid.

CUVARDIC GARCÍA, Dorde (2012), "El flâneur y la flaneuse en la historia de la pintura, el cine, la fotografía y la ilustración", Revista de Filología y Lingüística de la Universidad de Costa Rica, $\mathrm{n}^{\circ} 38$.

MITRY, Jean. (1974), Historia del cine experimental, Fernando Torres, València. 
MITTELL, Jason (2006), "Narrative Complexity in Contemporary American Television", The Velvet Light Trap, n 58, pp. 29-40.

MORAL, Javier (2016), "De la pintura al cine, del cine a la pintura: historias de una imantación", Eme, n 4, pp. 90-99.

MORAL, Javier (2004), "La cabecera fílmica en el biopic de artista"; Bellas Artes, $n^{\circ} 2$, 257-282.

ORTIZ, Áurea y PIQUERAS, María José (1995), La pintura en el cine, Paidós, Barcelona.

PROSPERI, Gabrielle (2017), "Tra TV e GIF quality: The Young Pope come esempio di complessità televisiva", Annali online della Didattica e della Formazione Docente, Vol. 9, $\mathrm{n}^{\circ}$ 12, Università degli Studi di Ferrara, pp. $119-136$.

RODRÍGUEZ SERRANO, Aarón (2017), “El hombre, el otro y Dios: reflexiones sobre la mirada y la serialidad en The Young Pope", L'Atalante: revista de estudios cinematográficos, $\mathrm{n}^{\circ} 24$. Asociación El camarote de Père Jules, Valencia.

RUBIO ALCOVER, Agustín (2012), "Sorrentino para diletantes"; Quaderni del CSCl, número 8.

SÁNCHEZ BIOSCA, Vicente (2004), Cine y vanguardias artísticas: conflictos, encuentros, fronteres, Paidós, Barcelona. 